\title{
Duchovní hudba a česká hudební kultura v devadesátých letech minulého století
}

\section{Duchovní hudba a česká hudební kultura v devadesátých letech minulého století}

\author{
Eva Vičarová / eva.vicarova@upol.cz \\ Department of Musicology, Faculty of Arts, Palacký University, Olomouc, CZ \\ Kateřina Janíčková / katerina.janickova@upol.cz \\ Department of Musicology, Faculty of Arts, Palacký University, Olomouc, CZ
}

\begin{abstract}
The study brings the synthetic overview of the Czech sacred music development in 19902000. The Czech musical culture has shown the significantly increased interest in the genre of sacred music as the result of political and social changes after 1989. In addition to the composers devoted themselves to this area even before the revolution, a number of them newly composed the sacred music. Important sacred works of the past have also often found their way into the repertoire of professional musical ensembles.

New institutions were established: Society of Sacred Music, Musica Sacra to provide the professional qualifications for church organists, church conservatories in Kroměřiž and Opava. Sacred music became the common topic in music periodicals, especially Hudební rozhledy (Music Review), Opus musicum and Harmonie. Since 1999, Varhaník (Organist) has been published. Recordings of sacred music and several monographs were published.
\end{abstract}

\section{Keywords}

sacred music, Czechoslovakia, Czech Republic, 1990-2000, Petr Eben, composers, compositions, music criticism, music festivals 


\section{Úvodem}

V důsledku změny politické a společenské situace po roce 1989 lze v české hudební kultuře vysledovat výrazně zvýšený zájem o žánr duchovní hudby. ${ }^{1}$ Kromě skladatelů věnujících se tomuto žánru i před revolucí se v duchovní hudbě nově realizovala celá řada dalších hudebních tvůrců. Bylo to přirozeným důsledkem nově nabyté svobody i společenské poptávky. Premiéry soudobých děl oživovaly koncertní řady symfonických, komorních i vokálních těles, programy tradičních či nově zakládaných hudebních festivalů i hojně organizovaných chrámových koncertů. Např. hned 33. ročník Festivalu sborového umění Jihlava zahájily dva chrámové koncerty (16.-18. listopadu 1990). Celou sekvenci skladeb a večerů duchovní hudby přirozeně iniciovaly jak návštěvy papeže Jana Pavla II. v Praze (1990), v Olomouci (1995) a v Hradci Králové (1997), tak také oslavy výročí sv. Václava, sv. Vojtěcha, příchodu sv. Cyrila a Metoděje na Velkou Moravu apod.

Do repertoáru profesionálních hudebních těles nalézala častěji cestu rovněž významná duchovní díla minulosti. ${ }^{2}$ Např. po zvolení Václava Havla prezidentem ČSSR 29. prosince 1989 zaznělo ve svatovítské katedrále v provedení České filharmonie a Pražského filharmonického sboru v čele s Liborem Peškem Dvořákovo Te Deum. Hned v prvních porevolučních letech se uskutečnily desítky představení Mozartova a Verdiho Requiem či skladeb A. Dvořáka (Stabat Mater, Requiem) Českou filharmonií, Pražskými symfoniky, Pražskou komorní filharmonií, ale i dalšími českými a moravskými symfonickými a vokálními tělesy. Československý, resp. Český rozhlas začal uvádět přímé přenosy bohoslužeb a pravidelné programy zaměřené na duchovní hudbu. Podobně tomu bylo i v Československé, resp. České televizi (např. Pocta katedrále v roce 1994, jedenáct dílů seriálu To nejlepši z klasiky zaměřených na duchovní hudbu od středověku do 20. století v roce 1997, Hudba na českých ki̛rech v roce 1999 apod.). Byla znovu obnovena činnost Společnosti pro duchovní hudbu (1942, resp. 1990), ${ }^{3}$ v Brně vznikla Jednota Musica Sacra (1993) nabízející odbornou kvalifikaci chrámových varhaníků, ${ }^{4}$ vznikly církevní konzervatoře v Kroměříži (1990; přesunutá později do Olomouce) a Opavě (1990).

1 Př́spěvek vznikl za podpory MŠMT ČR udělené UP v Olomouci (IGA_FF_2018_010 a IGA_FF_2019_006). Termín duchovní hudba bývá v širším slova smyslu používán jako střechový pojem zahrnující označení „církevní hudba“, „chrámová hudba“, „sakrální hudba“, „liturgická hudba“, „posvátná hudba“, „náboženská hudba“ apod., př́ípadně funguje jako jejich synonymum. V užším slova smyslu je jím označována hudba s náboženským obsahem vymezeným především svými křestanskými náměty (tedy i čistě instrumentální) nebo zpívanými texty a uváděná spíše v koncertní síni než v kostele. Hudba katolické církve provozovaná při bohoslužbě či během denní modlitby církve v kostele bude v dalším textu označena jako liturgická. Podrobnější vymezení těchto pojmů viz: FUKAČ, Jiří. Církevní hudba, chrámová hudba, duchovní hudba. In Slovnik české hudebni kultury, Jiř́i Fukač - Jiří Vysloužil - Petr Macek (eds.). Vyd. 1, Praha: Editio Supraphon, 1997, s. 98-99, 170. Stranou naší pozornosti pro př́ípad této studie zůstávají útvary Orientem inspirované duchovní hudby (např. projekty Vlastislava Matouška, židovská hudba), pravoslavná hudba atd.

2 V dalším textu se budeme zabývat pouze profesionální hudební kulturou. Amatérské a poloamatérské hnutí, které sehrálo v 90. letech v duchovním životě velmi podstatnou roli, ponecháme z důvodu omezeného rozsahu studie jen v podobě letmých zmínek.

3 [Cit. 2019-08-19]. Dostupné z: http://www.sdh.cz/.

4 [Cit. 2019-08-19]. Dostupné z: http://www.musicasacra.cz/. 
Otázky duchovní hudby v souvislosti s křestanskou duchovní kulturou se staly nosným tématem dobové reflexe na stránkách novin i odborných periodik; od roku 1999 vycházel časopis Varhanik. Nahrávky liturgické a duchovní hudby začaly být vydávány na hudebních nosičích, vědecké a vzdělávací instituce podněcovaly vznik odborných studiî s danou tematikou, vyšlo také několik knižních monografií. Následující text je pokusem o syntetický přehled vývoje české duchovní hudby v první porevoluční dekádě s důrazem na kompoziční tvorbu. ${ }^{5}$

\section{Skladatelé a jejich dílo}

V časech nově nabyté svobody duchovní hudba zůstala, příp. se stala mnoha autorům těžištěm jejich kompoziční činnosti. Tito skladatelé se již v devadesátých letech nemuseli obávat otevřeně vyjádřit svůj světový názor a zprostředkovat ostatním obecné křestanské hodnoty. Na prvním místě mezi ně patřili Jan Hanuš (1915-2004), ${ }^{6}$ Petr Eben (19292007)7 a Zdeněk Pololáník (1935), ${ }^{8}$ kteří ještě zintenzivnili své kompoziční úsilí rozvíjené v předchozích dekádách. Z příslušníků starší generace autorů, narozených ve 20. a 30. letech 20. století, zůstal nadále plodným také Jiří Laburda (1931). ${ }^{9} \mathrm{~K}$ nim dále přibyli také Svatopluk Havelka (1925-2009), ${ }^{10}$ Zdeněk Lukáš (1928-2007), ${ }^{11}$ Antonín Tučapský (1928-2014), ${ }^{12}$ Marek Kopelent (1933) ${ }^{13}$ a Jaroslav Krček (1939). ${ }^{14}$

5 Následující pojednání je výsledkem rozsáhlého pramenného výzkumu. Byly provedeny rešerše v časopisech Hudebni rozhledy a Opus musicum v období 1990-2000 a Harmonie v letech 1993-2000. Není-li uvedeno jinak, informace o autorech a jejich dílech byly získány z materiálů Hudebně informačního střediska a jeho on-line databáze [cit. 2019-08-19]. Dostupné z: https://www.musicbase.cz, z databáze Českého hudebního fondu [cit. 2019-08-19]. Dostupné z: http://noty.hudebnifond.cz/cz/index.html, prŕípadně z oficiálních webových stránek skladatelů.

6 Více viz: HANUŠ, Jan. Labyrint svět: svědectvi z konce času. 1. vyd. Praha: Odeon, 1996.

7 Více viz: VONDROVICOVÁ, Kateřina. Petr Eben. 1. vyd. Praha: Panton, 1995, VíTOVÁ, Eva. Petr Eben: sedm zamyšleni nad životem a dílem. 1. vyd. Praha: Baronet, 2004, PIRNER, Jan. Eben, Petr. Český hudebni slovnik [online]. [Cit. 2019-08-19]. Dostupné z: http://www.ceskyhudebnislovnik.cz/slovnik/index.php?option=com_ mdictionary\&task=record.record_detail\&id=6918.

8 Více viz: SOBOTKA, Mojmír. Pololáník, Zdeněk. Český hudebni slovnik [online]. [Cit. 2019-08-19]. Dostupné z: http://www.ceskyhudebnislovnik.cz/slovnik/index.php?option=com_mdictionary\&task=record.record_detai$1 \&$ id $=2822$.

9 Více viz: SEDLÁČKOVÁ, Simona. Laburda, Jiří. Český hudebni slovnik [online]. [Cit. 2019-08-19]. Dostupné z: http://www.ceskyhudebnislovnik.cz/slovnik/index.php?option=com_mdictionary\&task=record.record_detai$1 \&$ id $=676$.

10 Více viz: KRATOCHVÍlOVÁ, Jana. Havelka, Svatopluk. Český hudebni slovník [online]. [Cit. 2019-08-19]. Dostupné z: http://www.ceskyhudebnislovnik.cz/slovnik/index.php?option=com_mdictionary\&task=record. record_detail\&id $=6439$.

11 FIALA, Jaroslav. Operní a kantátové dílo. In Zdeněk Lukáš hudebni skladatel (1928-2007). Zdeněk Vimr (ed.). Vyd. 1. Praha: ASN repro, 2010.

12 Antonína Tučapského, přestože žil od roku 1975 trvale v Londýně, zařazujeme do studie proto, že v 90. letech byl v intenzivním kontaktu s českými zeměmi a jeho dílo se zde setkávalo s ohlasem. Více informací viz http://www.antonintucapsky.com. [Cit. 2019-08-19] 
Ze skladatelů střední generace, narozených ve 40 . letech, zaznamenáváme výrazné zacílení na duchovní hudbu u Františka Gregora Emmerta (1940-2015) ${ }^{15}$ a Ivana Kurze (1947). ${ }^{16}$ Významné kompoziční počiny lze nalézt také u Petra Fialy $(1943)^{17}$ a Milana Slavického (1947-2009). ${ }^{18}$

Autory narozené v 50. letech reprezentovali Jan Bernátek (1950), ${ }^{19}$ Jan Jirásek (1955), ${ }^{20}$ Pavel Zemek Novák (1957) ${ }^{21}$ a Radek Rejšek (1959). ${ }^{22}$ Nejmladší generaci skladatelů věnujících se v 90. letech duchovní tvorbě pak zastupoval Miloš Bok (1968). ${ }^{23}$

Výše zmínění autoři vytvořili mnoho duchovních skladeb nejrůznějších forem a druhů. Jednalo se o velké vokálně-instrumentální útvary (mešní cykly a oratoria) s doprovodem varhan a symfonického orchestru, ale i o drobnější formy hymnů, žalmů a modliteb ve sborové úpravě, případně o varhanní skladby ve formě fantazijních mešních vložek apod. Mnoho těchto děl vstoupilo do repertoáru sborových těles a jsou součástí jejich kmenového repertoáru doposud. Skladatelé se nevyhýbali ani čistě instrumentálním útvarům (nejčastěji symfonii).

Nejstarší ze skladatelů této generace, Jan Hanuš, zkomponoval např. Symfonii č. 7 Klíče králouství (1989-90) s textem Te Deum, Requiem: Missa VIII - Pro defunctis (1991-95), proprium Prosba Sv. Vojtěcha za jednotu světa (1996) pro dechový orchestr a symfonickou fresku Věže babylonské (1999). Zatímco v orchestrální hudbě Hanuš pracoval s hutným

13 Více viz: MATZNER, Michal. Kopelent, Marek. Český hudebni slovník [online]. [Cit. 2019-08-19]. Dostupné z: http://www.ceskyhudebnislovnik.cz/slovnik/index.php?option=com_mdictionary\&task=record.record_detail\&id=1459.

14 Více viz: ŠŤASTNÁ, Kateřina Alexandra. Krček, Jaroslav. Český hudebni slovnik [online]. [Cit. 2019-08-19]. Dostupné z: http://www.ceskyhudebnislovnik.cz/slovnik/index.php?option=com_mdictionary\&task=record. record_detail\&:id=5453.

15 Více viz: SPÁČILOVÁ, Jana. Emmert, František. Český hudební slovnik [online]. [Cit. 2019-08-19]. Dostupné z: http://www.ceskyhudebnislovnik.cz/slovnik/index.php?option=com_mdictionary\&task=record.record_detail\&id=1256.

16 ZAPLETAL, Petar. Kurz, Ivan. Český hudebni slovnik [online]. [Cit. 2019-08-19]. Dostupné z: http://www. ceskyhudebnislovnik.cz/slovnik/index.php?option=com_mdictionary\&task=record.record_detail\&id=459.

17 Více viz: MICHÁLKOVÁ SLIMÁČKOVÁ, Jana. Přehled skladatelů varhanni tvorby. Brno: JAMU, 2015.

18 ŠŤASTNÁ, Kateřina Alexandra. Slavický, Milan. Český hudebni slovnik [online]. [Cit. 2019-08-19]. Dostupné z: http://www.ceskyhudebnislovnik.cz/slovnik/index.php?option=com_mdictionary\&task=record.record_detail\&id $=6139$.

19 KALINA, Petr Ch. Bernátek, Jan. Český hudebni slovnik [online]. [Cit. 2019-08-19]. Dostupné z: http:// www.ceskyhudebnislovnik.cz/slovnik/index.php?option=com_mdictionary\&task=record.record_detai$18 \mathrm{cid}=1000739$.

20 SOBOTKA, Mojmír. Jirásek, Jan. Český hudebni slovnik [online]. [Cit. 2019-08-19]. Dostupné z: http://www. ceskyhudebnislovnik.cz/slovnik/index.php?option=com_mdictionary\&task=record.record_detail\&id=2770.

21 SÝKORA, Pavel. Zemek Novák, Pavel. Český hudebni slovnik [online]. [Cit. 2019-08-19]. Dostupné z: http:// www.ceskyhudebnislovnik.cz/slovnik/index.php?option=com_mdictionary\&task=record.record_detai$1 \& \mathrm{cid}=1001608$.

22 POLÁŠSK, Radek. Rejšek, Radek. Český hudebni slovnik [online]. [Cit. 2019-08-19]. Dostupné z: http:// www.ceskyhudebnislovnik.cz/slovnik/index.php?option=com_mdictionary\&task=record.record_detai$1 \&$ cid=1001064.

23 VLČEK, Jakub V. Bok, Miloš. Český hudebni slovnik [online]. [Cit. 2019-08-19]. Dostupné z: http://www.ceskyhudebnislovnik.cz/slovnik/index.php?option=com_mdictionary\&task=record.record_detail\&id=1000751. 
zvukem a architektonicky propracovanou fakturou, v dílech vokálních respektoval přirozenost lidského hlasu a harmonickou sazbu vyrůstající z české sborové tradice.

Největšího ohlasu v domácím i mezinárodním kontextu se dostalo tvorbě Petra Ebena. Na tzv. sametovou revoluci bezprostředně zareagoval oslavným hymnem Pražské Te Deum (1989). Jak zjistila Eva Vítová, zatímco v období totality tvořila duchovní díla $50 \%$ objemu jeho celkové kompoziční tvorby, po převratu se jednalo o $75 \% .{ }^{24}$ Eben je autorem opery Jeremias podle dramatu Stefana Zweiga (1996-7), oratorií (např. Posvátná znamení, 1992-93, Anno Domini, 1999), řady varhanních, sborových i komorních děl na žalmové a liturgické texty, modliteb apod., v nichž často vychází z gregoriánského chorálu a jehož idiomy kombinuje s moderní harmonií a výraznou rytmikou.

Zdeněk Pololáník vytvořil kromě ordinaria Setkáni (1995) několik komorních oratoriî se syntezátorem (Popelka Nazaretská, 1991, Napřed je třeba unést kř́ž, 1992, a Bůh je láska, 1993), Te Deum (1991-92), sborové žalmové i pastorální zpěvy (Chválospevy, 1993, a Cantus laetitiae, 1994), zhudebněné modlitby a skladby pro varhany. Pololáníkova hudba využívá rozšířenou tonalitu, stavbu v kontrastních blocích, netradiční zvukové kombinace a barvy.

Nejplodnějším skladatelem starší generace byl Jiří Laburda. Navázal na českou kantorskou tradici, dvořákovský styl i cyrilskou reformu, jež občas střídmě obohatil prvky aleatoriky a dodekafonie, a v neoklasicistním stylu komponoval mešní cykly s nejrůznějším hlasovým obsazením ((Missa pastoralis, 1990, Missa Sistina, 1993 nebo Missa Cum cantu populi, 1992, 1994), sborové mešní vložky, příležitostné zpěvy, aranžoval koledy, staročeské chorály a vytvářel chrámové sonáty (Sonada da chiesa No. 3. „Nativitas Christi“, pro trubku a varhany, 1997, či Sonata da chiesa No. 4. pro trubku, lesni rok a varhany, 1999).

Svatopluk Havelka svým - o tradici opřeným - jazykem založeným na výrazné metrorytmice a zvukové plnosti uplatnil biblické náměty ve skladbách vokálně instrumentálních (Parénéze, cyklus pěti zpěvů na řecké texty epištol pro soprán sólo, piano, dva hráče bicích nástrojů a speakra, 1993), symfonických (Znameni časů, 1996), i komorních (Soliloquia animae ad Deum / Rozhovory duše s Bohem pro klarinet a klavír, 1991, a Agapé je láska, 1998).

Doménou Zdeňka Lukáše byla vždy sborová tvorba. Mistrně dokázal čerpat z modality a melodických idiomů lidové hudby a využít přitom všech možností lidského hlasu. Pro jeho dílo je typická syntéza klasických hudebních postupů s moderní hudební řečí. Je autorem Missy brevis pro barytonové sólo a ženský sbor (1990), Mariánských pisni (1991), Liturgických pisni (1992), Requiem per coro miso (1992), oratoria Dies irae (1995), kantáty Lux aeternae (1998), řady sborů na Šalamounovy verše, vánočních zpěvů, modliteb a duchovních árií.

Také kompoziční styl Antonína Tučapského vycházel z jeho celoživotního provázání se sborovým zpěv. Jeho skladatelský jazyk se vyznačuje tradičními postupy. Ústřední složkou je melodie, s níž je pracováno na bázi rozšriřené tonality. Pozornost vzbudily jeho Missa Brevis (1994) a Missa de Angelis (1995), Te Deum s doprovodem varhan či symfonického orchestru (1999) a drobnější sborové kompozice pro smíšený sbor s doprovodem klavíru (Magnificat a Nunc Dimittis, obě 1998). 
Ojedinělého významu nabyla společná kompozice Requiem der Verzeihung (1994) k oslavě padesátého výročí konce 2 . světové války a uctění všech jejích obětí s premiérou 16 . srpna 1995, na níž se podílel rovněž Marek Kopelent, a to ve spolupráci s dalšími osobnostmi evropského formátu jako Krzystof Penderecki, Luciano Berio či Alfred Schnittke. Z další Kopelentovy duchovní tvorby je třeba připomenout také sborové skladby Cantus de prodefunctis (1994) a Cantus de nativitate filii (1997), oratorium o sv. Anežce Lux mirandae sanctitatis, oratorium pro soprán, recitátora, smíšený a dětský sbor a instrumentální ansámbl (1994) či komorní kantáta Cantus de dilectione filiarum dei (1998).

Jaroslav Krček se k duchovní hudbě přihlásil prostřednictvím pěti mešních cyklů pro sóla, sbor a komorní či velký orchestr, v nichž vyšel z bohatého studia folkloru a duchovních písní českých kancionálů. Např. Česká mše pro sóla, sbor a komorní orchestr byla složena v roce 1991 k poctě J. A. Komenského a zazněla na Pražském jaru 1992. Krček je rovněž autorem Vánočni mše (1990) či Mše č. 4 „Latinské“ (1996).

$\mathrm{Z}$ autorů střední generace zaujímá čelné místo - i co do počtu skladeb - František G. Emmert. Ten vytvořil v pojednávaném období pět symfonií (Symfonie č. 15 „Žalm 1“, 1990, Symfonie č. 16 „Útěcho zarmoucených“, 1990, Symfonie č. 18 „Osmé zastaveni Kř́žové cesty“, 1993, Symfonie č. 19 „Šimon z Cyrény“, 1995, a Symfonie č. 20 „Tři noci Svatého Josefa“, 1998), oratorium Ex aquam et Spiritus Sanctus (1995), několik komorních oratorií a řadu sborových, písňových i instrumentálních skladeb zpracovávajících tradičními kompozičními prostředky námět biblických žalmů a hymnů. Závažnými kusy stvrdil svou výraznou pozici mezi autory duchovní hudby Ivan Kurz, a to tetralogií oratorií na motivy Mariánských zjevení: Fatima stále aktuálni (1992), Maria vykládá Apokalypsu (1993), Velká očista (1995), Naděje (1996), duchovní opery Večerni shromážděni (1989-90), ale i dalších skladeb vokálně-instrumentálních (Advent, 1993). Kultivovaný, barvitý, tektonicky promyšlený a sdělný hudební styl Kurzových skladeb vynesl autora mezi nejvlivnější skladatele své generace.

Tři oratoria vytvořil za uplatnění tradiční kompoziční práce s vytříbeným smyslem pro vokální linii Petr Fiala: Píseň sestry Anežky a bratra Františka (1990), Křest svaté Ludmily (1992) a Pocta Janu Sarkanderovi (1994).

Duchovní kompozice Milana Slavického využívají jak elektroakustické prostředky ( $A d$ ventus, 1992), tak z tradice vycházející jazyk opřený o promyšlenou tektoniku, uplatněný ve skladbách rozmanitého obsazení: velkého symfonického (Porta coeli, 1991, jež získala Cenu české kritiky za nejlepší provedenou skladbu v roce 1992, a Dvě kapitoly z Apokalypsy, 1995) či komorního vokálního (Media vita I pro soprán a violu, 1989, Veni, Sancte Spiritus, 1998, Regina coeli, 1999).

Nejplodnějším autorem mezi skladateli narozenými v 50. letech se v oblasti duchovní hudby stal brněnský Pavel Zemek Novák. Hned v roce 1990 obdržel druhé místo v Soutěži mladých skladatelé ČR za Valčiky. Poctu sv. Františkovi z Assisi. Novákova tvorba vychází jednoznačně z tradice a obsahuje jak čistě instrumentální sólové kusy, v nichž realizuje vlastní metodu jednohlasé nástrojové hry v delších časových plochách (Chrámové sólo pro sólový klarinet, 1993), tak skladby komorní či symfonické určené pro akustiku chrámu (Symfonie č. 2 „Pašije podle sv. Jana“ pro 9 sólistů, smíšený sbor a orchestr, 1990-1997, za niž získal cenu Jubilejní cenu Leoše Janáčka). 
Sónické a témbrové plochy, ostinata, ale i minimalistické patterny propojené s tradiční hudební bází jsou příznačné pro kompozice Jana Jiráska. Ty našly velkou oblibu u pěveckých těles různých obsazení a existují proto v několika verzích. Jedná se zejména o skladbu Missa propria, 1993. Postmoderně orientován je také hymnus Te Deum Laudamus, 1999, pro smíšený či chlapecký sbor na liturgický text a budhistické mantry. Ojedinělé postavení mají v Jiráskově tvorbě také Pašije sv. Lukáše, premiérované v Mnichově v roce 1996, které rekonstruoval podle Bachova rukopisu a dokomponovaných pasáží Carla Orffa.

Z větších kompozic Radka Rejška vstoupily do širšího povědomí Passio. Janovy pašije pro barytonové sólo, scholu a varhany (1995) a Missa brevis pro smíšený sbor a varhany (1999), z drobnějších např. Ave Maria (1996), Otče náš (1998) či Salve Regina (1999), komponované opět v tradičním duchu.

Kompozice Jana Bernátka navazují na tradici české kantorské tvorby. Z větších děl stojí za zmínku oratorium Písně Šalamounovy (1991), Missa brevis (1993) či kantáty, často v obsazení sólový zpěv, smíšený sbor a varhany či komorní orchestr (Kř̌žzová cesta, 1992, Adventni kantáta, 1993, Vánočni kantáta, 1994, Svatý Vojtěch, 1996, či Výstup na horu Karmel, 1997).

Specifické místo mezi výše uvedenými skladateli několika generací přísluší Miloši Bokovi, jenž zcela rezignoval na světskou sféru a své kompoziční úsilí nasměroval výlučně k oslavě Boha. Bok, stylově vycházející z hudební řeči pozdního romantismu, se do povědomí širší veřejnosti v daném období zapsal zejména prostřednictvím oratoria Skřítkové z Krinického údoli (1993), finále z dalšího oratoria Svatá Zdislava (1998) a Symfonických koled (1999).

Liturgické a duchovní skladby komponovala v 90. letech minulého století celá řada dalších českých autorů. Inspirovali se historickou, estetickou, kulturní i nadčasovou nosností jejích útvarů. Tímto způsobem vyjádřili svou osobní víru, reagovali na aktuální osobní či společenské události, přihlásili se k anticko-židovsko-křestanským kořenům naší civilizace, příp. vyhověli objednávce konkrétních interpretů a zpěváků, vokálních či instrumentálních těles, festivalových výborů či skladatelských soutěží. Kompoziční řeč uplatněná v jejich skladbách byla opět velmi pestrá: Navazovala na tradicionalismus i výdobytky modernismu, reagovala na avantgardu i postmoderní syntézu, přinášela fúze s jazzem i folklorem. Ze starší skladatelské generace je třeba připomenout Klementa Slavického, Ilju Hurníka, Viktora Kalabise, Aloise Piňose, Zdeňka Šestáka, Karla Skleničku, Jiřrího Temla nebo Jana Málka. Střední generaci autorů zastupovali Rudolf Růžička a Jan Grossmann, ze skladatelské generace narozené v 50. letech stojí za zmínku Otomar Kvěch, Peter Graham, Sylvie Bodorová, Juraj Filas, Jiří Gemrot a Zbyněk Matějů, nejmladší skladatele pak reprezentovali František Fiala, Lukáš Hurník a Robert Hejnar.

Na fúzi folkloru s vážnou hudbou se zaměřil Jiří Pavlica, jazzové prvky obohatily duchovní tvorbu prostřednictvím Karla Růžičky st. a Ladislava Simona. 


\section{Koncertní uplatnění a studiové nahrávky}

Jak již bylo zmíněno, v průběhu 90 . let zařazovali dramaturgové našich předních orchestrů či festivalů do koncertních sezon významná duchovní díla evropské hudební historie. Novinkové duchovní kompozice bylo možno zaregistrovat jednak v programech renomovaných hudebních festivalů, jako např. Pražské jaro (1946), Moravský podzim (1966), Olomoucké hudebni jaro (1959) nebo Janáčkiov máj (1976), jednak v rámci Dnů soudobé hudby (1990) pořádaných Společností českých skladatelů ve spolupráci se Společností pro duchovní hudbu.

Svobodná a demokratická 90 . léta dala vzniknout několika novým festivalům, přednostně zaměřeným na duchovní hudbu, z nichž některé existují dodnes. Hned v roce 1990 byl v Kroměříž založen Forfest, mezinárodni festival soudobého uměni s duchovním zaměrenim ${ }^{25}$ a začal být pořádán Mezinárodni festival duchovni hudby v Nymburce.$^{26} \mathrm{O}$ rok později se jednalo o ekumenickou přehlídku pop music s křestanským zaměřením Vox clamantis v Praze, ${ }^{27}$ v roce 1992 pak o další dva festivaly: Velikonočni festival duchoun hudby v Brně ${ }^{28}$ a pražské Svatováclavské slavnosti - festival duchovního umění, za nímž stála Společnost pro duchovní hudbu. ${ }^{29} \mathrm{~V}$ roce 1993 byl založen Mezinárodni festival vokálni duchovni hudby v Šumperku s bienálním časovým sledem, ${ }^{30}$ a v roce 1994 Podzimni festival duchovni hudby v Olomouci, ${ }^{31}$ Festival duchovni hudby Odry ${ }^{32}$ a přehlídka Musica Spiritualis Ecumenica.

Nahrávky historických i soudobých českých kompozic duchovní hudby realizoval po roce 1989 zejména Supraphon a Panton (do roku 1999), od roku 1995 akciová společnost Radioservis a některá další soukromá vydavatelství a nahrávací společnosti.

\section{Teorie, kritická reflexe a recepce}

K odborným počinům 90. let patří Stručný slovnik duchovni hudby Jiř́ho Vyskočila, ${ }^{33}$ stopadesátistránková syntetická práce Miloslava Bučka Duchovni hudba 20. stoleti,$^{34}$ Stručný

25 [Cit. 2019-08-19]. Dostupné z: https://www.forfest.cz/.

26 Dnes Nymburské dny Bohuslava Matěje Černohorského. [Cit. 2019-08-19]. Dostupné z: http://www.nkc-nymburk.cz/index.php?sekce=8\&zobraz=vox-nymburgensis.

27 Později festival VOX.

28 [Cit. 2019-08-19]. Dostupné z: https://filharmonie-brno.cz/velikonocni-festival-duchovni-hudby.

29 [Cit. 2019-08-19]. Dostupné z: http://svs.sdh.cz/?page_id=55.

30 [Cit. 2019-08-19]. Dostupné z: https://www.navstivtejeseniky.cz/akce/mezinarodni-festival-duchovni-vokalni-hudby-204166.

31 [Cit. 2019-08-19]. Dostupné z: http://www.podzimni-festival.cz.

32 [Cit. 2019-08-19]. Dostupné z: http://m.odry.cz/ap.

33 VYSKOČIL, Jiří. Stručný slovnik duchovni hudby. 2. vyd. Čelákovice: Městské muzeum, 1993.

34 BUČEK, Miloslav. Duchovni hudba 20. století. 1. vyd. Brno: Masarykova univerzita v Brně, 1999. 
přehled dějin katolické chrámové hudby Jiřího Sehnala ${ }^{35}$ a monografie Kateřiny Vondrovicové Petr Eben. ${ }^{36}$

Dění v oblasti duchovní hudby přirozeně sledoval i odborný tisk. ${ }^{37} \mathrm{~V}$ Hudebnich rozhledech se v první porevoluční dekádě objevilo ročně zhruba 40 článků, které pojednávaly o duchovní hudbě.

Ze skladatelů se nejčastěji psalo o Petru Ebenovi. V souvislosti s jeho jménem zde bylo nalezeno 23 článků. Na pomyslném druhém místě se umístil Jan Hanuš (8 článků), na třetím Svatopluk Havelka (7), na čtvrtém Antonín Tučapský, Marek Kopelent a Miloš Bok (5), na pátém pak Zdeněk Pololáník, Zdeněk Lukáš a Petr Fiala (4). Toto pořadí dosvědčuje význam a ohlas zmíněných skladatelů a jejich děl ve společenské atmosféře 90. let minulého století.

Významné místo mezi nalezenými články zaujímají studie se seriálovým názvem $D u$ chovni svět v životě a v hudbě Petra Ebena, ${ }^{38}$ Ivana Kurze ${ }^{39}$ a Jana Hanuše. ${ }^{40}$ Podobné ladění měl rozhovor s Pavlem Zemkem. ${ }^{41} \mathrm{~V}$ rubrice „Představujeme skladbu“ poskytla redakce časopisu prostor dvěma dílům: Media vita I Milana Slavického ${ }^{42}$ a Perenézé Svatopluka Havelky. ${ }^{43} \mathrm{~V}$ rubrice „Komentáře“ byly představeny Orffovy-Jiráskovy Lukášouy pašije. ${ }^{44}$

Časopis Harmonie uveřejnil v letech 1993-2000 ročně zhruba 20 článků týkajících se duchovní hudby. Opět asi jejich polovina se zaměřila na hudbu současnou. ${ }^{45}$ I v tomto časopise se nejčastěji psalo o Petru Ebenovi (14 článků), dále o Sylvii Bodorové (4 články), Marku Kopelentovi, Janu Jiráskovi a Milanu Slavickém (3 články). Nad současnou podobou hudby určené k liturgii se zamýšleli Lukáš Hurník ${ }^{46}$ a Petr Eben. ${ }^{47}$ Časopis

35 SEHNAL, Jiří. Stručný přehled katolické chrámové hudby. 1. vyd. Rosice, 1999.

36 VONDROVICOVÁ, op. cit .

$37 \mathrm{~V}$ následujících řádcích bude věnována hlavní pozornost odbornému tisku. Co se týká denního tisku, vzhledem k tomu, že jeho úkolem je přinášet informace o aktuálních kulturních událostech širokého dosahu, byla tematika duchovní hudby na jeho stránkách zastoupena jen v př́ípadech zcela mimořádných. Z důvodu velké časové náročnosti nebylo ovšem možné provést rešerši všech deníků a jejich krajských mutací. Články věnující se duchovní hudbě bylo možno sporadicky nalézt také v Katolickém týdeniku.

38 VONDROVICOVÁ, Kateřina. Duchovní svět v životě a v hudbě Petra Ebena, Hudebni rozhledy, 1991, roč. 44 , č. 9, s. 421-426.

39 VONDROVICOVÁ, Kateřina. Duchovní svět v myšlenkách a v hudbě Ivana Kurze. Hudebni rozhledy, 1991, roč. 44, č. 12, s. 529-531.

40 DOBROVSKÁ, Wanda. Duchovní svět v životě a hudbě Jana Hanuše. Hudební rozhledy, 1992, roč. 45, č. 1, s. $6-9$.

41 MÜLLER, Lubomír Ben. Duchovní svět Pavla Zemka. Zklidněte se a poslouchejte... Hudebni rozhledy, 1992 , roč. 45 , č. 6 , s. 250-252.

42 ŠMOLÍK, Jan. Milana Slavického Media vita I. Hudebni rozhledy, 1994, roč. 47, č. 9, s. 2-4.

43 ZAPLETAL, Petar. Svatopluka Havelky Parénéze. Hudebni rozhledy, 1994, roč. 47, č. 11, s. 5-7.

44 SLAVÍKOVÁ, Jitka. Carl Orff - Jan Jirásek - Lukášovy pašije (podle rukopisu J. S. Bacha). Hudebni rozhle$d y, 1995$, roč. 48 , č. $11,34-35$.

45 Časopis Harmonie začal být vydáván v roce 1993, kdy vyšla čtyři čísla. Od roku 1994 vycházel pravidelně každý měsíc.

46 HURNÍK, Lukáš. Azyl. Harmonie, 1997, roč. 5, č. 6, s. 3.

47 EBEN, Petr. Česká duchovní hudba 20. století. Harmonie, 1994, roč. 2, č. 12, s. 28-29, VÍTOVÁ, Eva. Zamyšlení Petra Ebena. Harmoie, 1999, roč. 7, č. 3, s. 4. 
přinesl také analýzy skladeb Petra Ebena (Jeremias) ${ }^{48}$ a Marka Kopelenta a jeho zahraničních spoluautorů (Requiem smîrenî). ${ }^{49}$

Brněnská hudební revue Opus musicum nabídla ve sledované dekádě k tématu duchovní hudby každoročně několik článků ${ }^{50}$ Jednalo se o celkové recenze festivalů (prim zde hrál Forfest Kroměříž), případně o studie věnované autorským profilům skladatelů působících v Brně, Františka G. Emmerta ${ }^{51}$ a Rudolfa Růžičky. ${ }^{52}$ Pokud byly recenzovány jednotlivé koncerty, pak se zájem redaktorů a kritiků zaměřil na Pavla Zemka Nováka, Miloslava Ištvana, Zdeňka Zouhara či Zdeňka Pololáníka.

Vědecké studie zaměřené na historii chrámové hudby bylo možno nalézt také v časopise Hudebni věda, a to zejména v textech Jiř́iho Sehnala.

\section{Závěrem}

Provedený výzkum prokázal, že atmosféra svobodného státu v období po převratu v roce 1989 ovlivnila velmi pozitivně fungování a rozvoj žánru duchovní hudby. Počet i umělecká hodnota skladeb, které čeští autoři vytvořili, stejně jako množství koncertů a nově vzniklých festivalů, charakter recepce i odborná reflexe dokazují, že tato oblast se v 90. letech těšila velké pozornosti odborné a oblibě širší hudební veřejnosti. S trochou nadsázky lze tvrdit, že duchovní hudba zaujala v kultuře a umění české společnosti 90 . let stejně důležité místo jako dříve potlačovaná a zamlčovaná exilová literatura či divadelní tvorba zakázaných autorů.

\section{Bibliography}

BUČEK, Miloslav. Duchovni hudba 20. století. 1. vyd. Brno: Masarykova univerzita v Brně, 1999. CIKRLE, Karel. Koncerty v kostelích. Opus musicum, 1991, roč. 23, č. 1, s. 29-30.

DOBROVSKÁ, Wanda. Duchovní svět v životě a hudbě Jana Hanuše. Hudebni rozhledy, 1992, roč. 45 , č. 1 , s. $6-9$.

EBEN, Petr. Česká duchovní hudba 20. století. Harmonie, 1994, roč. 2, č. 12, s. 28-29,

FIALA, Jaroslav. Operní a kantátové dílo. In Zdeněk Lukáš hudebni skladatel (1928-2007). Zdeněk

Vimr (ed.). Vyd. 1. Praha: ASN repro, 2010.

FUKAČ, Jiří. Církevní hudba, chrámová hudba, duchovní hudba. In Slovnik české hudebni kultury, Jiří Fukač - Jiří Vysloužil - Petr Macek (eds.). Vyd. 1, Praha: Editio Supraphon, 1997, s. 98-99, 170.

48 VEBER, Petr. Petr Eben: Tonalitu, motivy a témata jsem nikdy neopustil. Harmonie, 1997, roč. 5, č. 5, s. $40-41$.

49 STEHLÍKOVÁ, Ivana - VEBER, Petr. Requiem smíření. Harmonie, 1995, roč. 3, č. 10, s. 4-5.

50 Opus musicum byl vydáván do roku 1994 v počtu deseti čísel ročně. Od roku 1995 se se stal dvojměsičníkem a vycházel šestkrát za rok.

51 ŠTĚDROŇ, Miloš. Jaká je hudba Františka Emmerta? Opus musicum, 1990, roč. 22, č. 6, s. 183-185.

52 KADUCH, Miroslav. Crucifixion I. Opus musicum, 1996, roč. 28, č. 2, s. 57-60. 
HANUŠ, Jan. Labyrint svět: svědectvi z konce času. 1. vyd. Praha: Odeon, 1996.

HURNÍK, Lukáš. Azyl. Harmonie, 1997, roč. 5, č. 6, s. 3.

KADUCH, Miroslav. Crucifixion I. Opus musicum, 1996, roč. 28, č. 2, s. 57-60.

MICHÁLKOVÁ SLIMÁČKOVÁ, Jana. Přehled skladateli̊ varhanni tvorby. Brno: JAMU, 2015.

MÜLLER, Lubomír Ben. Duchovní svět Pavla Zemka. Zklidněte se a poslouchejte... Hudební rozhle$d y, 1992$, roč. 45 , č. 6 , s. 250-252.

NEDĚLKA, Michal. Mše v soudobé české hudbě. Praha: Karolinum, 2005.

SEHNAL, Jiří. Stručný prehled katolické chrámové hudby. 1. vyd. Rosice, 1999.

SLAVÍKOVÁ, Jitka. Carl Orff - Jan Jirásek - Lukášovy pašije (podle rukopisu J. S. Bacha). Hudebni rozhledy, 1995, roč. 48, č. 11, 34-35.

SLAVÍKOVÁ, Jitka. Bez hranic je katedrála hudby ducha. Hudebni rozhledy, 1990, roč. 43, č. 12, s. 531-532.

STEHLÍKOVÁ, Ivana - VEBER, Petr. Requiem smíření. Harmonie, 1995, roč. 3, č. 10, s. 4-5.

ŠMOLÍK, Jan. Milana Slavického Media vita I. Hudebni rozhledy, 1994, roč. 47, č. 9, s. 2-4.

ŠTĚDROŇ, Miloš. Jaká je hudba Františka Emmerta? Opus musicum, 1990, roč. 22, č. 6, s. 183-185.

VEBER, Petr. Petr Eben: Tonalitu, motivy a témata jsem nikdy neopustil. Harmonie, 1997, roč. 5, Č. 5, s. 40-41.

VÍTOVÁ, Eva. Petr Eben: sedm zamyšleni nad životem a dilem. 1. vyd. Praha: Baronet, 2004

VONDROVICOVÁ, Kateřina. Petr Eben. 1. vyd. Praha: Panton, 1995.

VONDROVICOVÁ, Kateřina. Duchovní svět v životě a v hudbě Petra Ebena, Hudebni rozhledy, 1991, roč. 44, č. 9, s. 421-426.

VONDROVICOVÁ, Kateřina. Duchovní svět v myšlenkách a v hudbě Ivana Kurze. Hudebni rozhle$d y, 1991$, roč. 44, č. 12 , s. 529-531.

VYSKOČIL, Jiří. Stručný slovnik duchovni hudby. 2. vyd. Čelákovice: Městské muzeum, 1993.

ZAPLETAL, Petar. Svatopluka Havelky Parénéze. Hudebni rozhledy, 1994, roč. 47, č. 11, s. 5-7. 
